\title{
U-Pb zircon (CA-ID-TIMS) age supports globally synchronous Sturtian deglaciation
}

Grant M. Cox ${ }^{1 *}$, Vincent Isakson², Paul F. Hoffman ${ }^{3}$, Thomas M. Gernon ${ }^{4}$, Mark D. Schmitz², Sameh Shahin ${ }^{1}$, Alan S. Collins ${ }^{1}$, Wolfgang Preiss ${ }^{1}$, Morgan L. Blades ${ }^{1}$, Ross N. Mitchell ${ }^{5}$, Adam Nordsvan ${ }^{5}$

1. Centre for Tectonics, Resources and Exploration (TraX), Department of Earth Sciences, The University of Adelaide, Adelaide, SA 5005, Australia.

2. Department of Geosciences, Boise State University, 1910 University Drive, Boise, Idaho. 3. Department of Earth and Planetary Sciences, Harvard University, Cambridge, MA 02138, USA.

4. Ocean and Earth Science, University of Southampton, European Way, Southampton SO14 3ZH, UK.

5. Department of Applied Geology, Curtin University, Bentley, Western Australia 6845, Australia

\section{Abstract}

* Corresponding author: grant.cox@adelaide.edu.au

A central prediction of the Snowball Earth hypothesis is that glacial onset should be synchronous at low latitudes, and its termination should be rapid and synchronous globally. High precision $\mathrm{U} / \mathrm{Pb}$ zircon ages provide supporting evidence for the synchronous onset (within error) of the Sturtian glaciation (ca. $716 \mathrm{Ma}$ ) on multiple continents. Successful application of Re-Os techniques on organic rich shales and carbonates allow for the possibility of a globally synchronous Sturtian deglaciation (ca. $660 \mathrm{Ma}$ ), but the sparse isotopic age constraints leave this open to debate. Here we report the first high precision U-Pb zircon age of $663.03 \pm 0.11$ Ma $(2 \sigma)$ for the end Sturtian recorded in the Bolla Bollana Formation of South Australia. This age supports previously published ages and is permissive with a globally synchronous deglaciation. In conjunction with the timing of glacial onset, this age reinforces the ca. $58 \mathrm{Myr}$ duration of the Sturtian Snowball.

Keywords: Snowball Earth, Sturtian, Synchronous Deglaciation, CA-ID-TIMS

\section{Introduction}

Some of the most extreme climate episodes the Earth has experienced occurred during a protracted phase of near-global glaciations in the Cryogenian period (720-635 Ma). These "Snowball” glaciations (Hoffman et al., 1998; Kirschvink, 1992), or cryochrons (Hoffman et al., 2017) are evidenced by the wide distribution of glacial deposits, particularly those associated with carbonate platforms, with the implication that glaciers entered the marine realm 
in the warmest areas (Harland, 1964; Kirschvink, 1992), along with sedimentary and palaeomagnetic evidence for grounded low latitude ice sheets (Evans, 2000; Hoffman and Schrag, 2002). While debate over the exact nature of these glaciations has ensued (e.g. Allen and Etienne, 2008; Eyles and Januszczak, 2004; Le Heron et al., 2011; Williams et al., 2016), the Snowball Earth hypothesis presents a holistic model when all relevant observations and modelling results are considered (Hoffman et al., 2017).

Many mechanisms have been proposed to explain the descent into the Snowball Earth climate state, including: enhanced silicate weathering associated with the emplacement of several large igneous provinces (Cox et al., 2016b; Godderis et al., 2003); nutrient induced enhancement in primary productivity (Cox et al., 2016b; Gernon et al., 2016; Horton, 2015); a reduction in volcanic degassing from continental arcs (McKenzie et al., 2016); and increased albedo due to volcanic sulphate aerosol emission (Macdonald and Wordsworth, 2017). Indeed, none of these mechanisms are mutually exclusive and long term global cooling could be due to feedbacks between these factors in conjunction with an a low-latitude continental configuration (Li et al., 2013; Merdith et al., 2017), which favours a cooler planet (Kirschvink, 1992). Regardless of the cause(s) of long term climate forcing, a variety of 1-D energy-balance models (Budyko, 1969; North et al., 1981; Sellers, 1969) and 3-D general circulation models (Abbot et al., 2013) exhibit an instability, or bifurcation: a point at which ice-albedo feedback becomes self-sustaining and ice lines progress rapidly and unstoppably to the equator.

Emergence from these global glaciations is linked to the sub-zero temperatures of the Snowball climate state and by consequence a restricted hydrological cycle that inhibits atmospheric $\mathrm{CO}_{2}$ scrubbing through silicate weathering. Ultimately, this process allows atmospheric $\mathrm{CO}_{2}$ to reach levels sufficient to overcome the ice-albedo feedback (Kirschvink, 1992). 
As the Snowball Earth model is tied to ice-albedo feedback followed by extreme greenhouse warming, a central prediction of the hypothesis is that the onset should be synchronous at low latitudes, and its termination should be rapid and globally synchronous. Testing for synchronicity relies heavily on a scaffold of isotopic U-Pb ages obtained from zircon-bearing volcanic ash beds and Re-Os ages from black shales from multiple and globally distributed correlated sequences.

To date, high precision U-Pb zircon ages for the Sturtian glaciation have demonstrated the onset of glaciation on several continents occurs between ca. 719 to ca. 710 (Bowring et al., 2007; Cox et al., 2015; Lan et al., 2014; Macdonald et al., 2010; Macdonald et al., 2017; Song et al., 2017; Zhou et al., 2004) (Table 1a). Furthermore, lower precision Re-Os ages on black shales from Australia, North America and Mongolia (Kendall et al., 2006; Rooney et al., 2014; Rooney et al., 2015) and a low precision U-Pb zircon age for South China (Yu et al., 2017), hint at a globally synchronous termination (Table $1 \mathrm{~b})$.

Here we report the first high precision chemical abrasion isotope dilution thermal ionization mass spectrometry (CA-ID-TIMS) U-Pb zircon age for the termination of the Sturtian glaciation along with supporting detrital zircon ages. These ages establish the timing of deglaciation of the Sturtian glaciation in Australia and is consistent with a globally synchronous end of the Sturtian glaciation at ca. $660 \mathrm{Ma}$ and its ca. $58 \mathrm{Myr}$ duration (Macdonald et al., 2010).

\section{Geologic Setting}

The Sturtian and Marinoan Series, along with the older Torrensian and Willouran, were defined as chronostratigraphic subdivisions of the Adelaide System by Mawson and Sprigg (1950). The Sturtian was characterised by, but not restricted to, sediments of glacial origin first recognised by Howchin (1901) in Sturt Gorge near Adelaide; it also includes the underlying Belair Subgroup of the Burra Group and the overlying Tapley Hill Formation. Subsequent 
mapping by the Geological Survey of South Australia established the wide distribution of glaciogenic sedimentary rocks of both Sturtian and Marinoan age. Together with an intervening succession of interglacial origin, these are grouped as the Umberatana Group of the Adelaide Rift Complex (Thompson et al., 1964), and are best exposed in the Flinders, Willouran and Gammon Ranges of South Australia (Fig. 1). However, Sturtian glacials are found discontinuously throughout the basin, including the first discovery (the Sturt Tillite) near Adelaide. Other lithostratigraphic names have been applied in other regions of the basin: Appila Formation in the Mid-North, Pualco Formation in the Olary Ranges and Bolla Bollana Formation in the northern Flinders Ranges. In the central Flinders and Olary Ranges, laminated siltstone (Benda Siltstone) and bedded ironstones (Holowilena and Braemar Ironstones) with dropstones are closely associated (Cox et al., 2016a; Le Heron et al., 2011; Lechte and Wallace, 2015; Lottermoser and Ashley, 2000). Basal Sturtian glacials rest on prominent erosional surfaces cut into a wide variety of older rocks (mostly Burra Group, but also Callanna Group and crystalline basement near the basin margins). The Wilyerpa Formation in the central Flinders and Olary Ranges overlies these rocks, locally unconformably, and is considered to represent the waning stages of the Sturtian glaciation, while the Lyndhurst Formation in the north-eastern Flinders Ranges is a likely equivalent (Preiss, 2000). The whole Sturtian glacial succession comprises the Yudnamutana Subgroup, the geology and tectonic setting of which was summarised by Preiss (2000) and Preiss et al., (2011).

The Yudnamutana Subgroup varies considerably in thickness from $\sim 100 \mathrm{~m}$ to over $5000 \mathrm{~m}$, reflecting local tectonic control. Extremely thick sections of the Yudnamutana Subgroup were deposited in actively extending grabens in the eastern (Baratta Trough) and north-eastern Flinders Ranges (Yudnamutana Trough) regions. The characteristic Cryogenian ironstones are found only in the Baratta Trough. The combination of ice rafted debris and diamictite with striated clasts overwhelmingly demonstrate the glaciogenic nature of the 
Yudnamutana Subgroup.

In the northern extent of the rift complex, within the Gammon and Willouran Ranges, the Bolla Bollana Formation is $\sim 1500 \mathrm{~m}$ thick near Arkaroola and contain abundant ice-rafted debris along with rare striated clasts (Le Heron et al., 2014). To the west and north-west, near Copley and Termination Hill (Fig. 1a), the Bolla Bollana Formation is comparatively thin reaching a maximum thickness $\sim 150 \mathrm{~m}$ (Fig. $1 \mathrm{~b} / \mathrm{c}$ ), with direct evidence for glaciation limited to abundant ice-rafted debris (Fig. 2). The glacial deposits in these localities overlie the preSturtian Myrtle Springs Formation (Fig. 1b/c).

Previous age constraints on the Sturtian glaciation in South Australia include a maximum depositional age on the much older Skillogalee Dolomite of $792 \pm 6 \mathrm{Ma}(2 \sigma)$ (Preiss et al., 2009), and a Re-Os black shale age from the lower part of the Tapley Hill Formation of $645.1 \pm 4.8 \mathrm{Ma}(2 \sigma)$ and $647 \pm 10 \mathrm{Ma}(2 \sigma)$ (Kendall et al., 2006). A complementary Re-Os age 657.2 $\pm 5.4 \mathrm{Ma}(2 \sigma)$ (Kendall et al., 2006) for the basal Aralka Formation, which overlies Sturtian glacials in the Amadeus Basin of the Northern Territory of Australia, constrains the Sturtian glaciation in Australia to be between ca. 798 Ma and ca. 657 Ma. A U-Pb SHRIMP age of $659 \pm 6 \mathrm{Ma}(2 \sigma)$ on the thin tuff band in the Bolla Bollana Formation at the Copley section has been reported in abstract (Fanning and Link, 2006, 2008).

\section{Geochronology}

Age of tuff in the Bolla Bollana Formation at Copley

Zircon crystals where analysed from a $\sim 3 \mathrm{~cm}$ thick tuff horizon within the Bolla Bollana Formation (Fig. 2). This horizon occurs $\sim 80 \mathrm{~m}$ below the contact with the non-glacial Tindelpina Shale Member of the Tapley Hill Formation (Fig. 2). These zircons were screened via cathodoluminescence imaging and in situ LA-ICP-MS analysis prior to selection and analysis by CA-ID-TIMS using methods described by Macdonald et al. (2017). All crystal 
fragments yield concordant analyses with dates between ca. $663 \mathrm{Ma}$ and ca. $667 \mathrm{Ma}$ (Fig. 3). Several older crystals are interpreted to record crystal inheritance into the volcanic population, a common phenomenon in silicic volcanic eruptions. The sixteen youngest grains form a statistically equivalent cluster with a weighted mean age of $663.03 \pm 0.11 \mathrm{Ma}(2 \sigma-\mathrm{MSWD}=$ 0.52 , probability of fit $=0.93$ ), which is interpreted as the igneous crystallization age of the zircons and the depositional age of the tuff. When tracer calibration and ${ }^{238} \mathrm{U}$ decay constant uncertainties are propagated in quadrature, the total error is $663.03 \pm 0.76 \mathrm{Ma}(2 \sigma)$, which should be considered when comparing our dates with those derived from the ${ }^{187} \mathrm{Re}^{187} \mathrm{Os}$ decay scheme (i.e. as presented in Table 1).

Bolla Bollana detrital zircon ages and provenance

Pre-Neoproterozoic detrital zircons from the Bolla Bollana Formation (sample W16-09 and W16-10; Fig. 1c) which were analysed via LA-ICP-MS (see supplementary material for further details), preserve $\mathrm{U}-\mathrm{Pb}$ ages consistent with a relatively local provenance from the west and northwest. The Neoarchean-Paleoproterozoic Sleaford/Mulgathing Complexes of the central and southern Gawler Craton (ca. 2.4-2.5 Ga) are consistent with sourcing zircons of this age in both samples. The rare earlier Neoarchean to Mesoarchean grains may be recycled from metasedimentary gneisses in the Mulgathing Complex, where detrital grains of Mesoarchaean age are preserved (McAvaney, 2012). The majority of detrital zircon grains in both samples yield ages between ca. 1.80 and $1.55 \mathrm{Ga}$, these ages being common in the eastern Gawler Craton where they overlap with the ca. 1.86-1.8 Ga Cornian Orogeny and Donington Suite, the extensive ca. 1.73-1.69 Ga Kimban Orogeny and associated granitoids, the ca. 1.621.61 Ga St Peter Suite and the voluminous ca. 1.59-1.57 Ga Hiltaba siliceous large igneous province (Hand et al., 2007). The latter province comprises the Hiltaba Suite granitoids and the bimodal Gawler Range Volcanics. Felsic protoliths of ca. 1.7-1.5 Ga age are also common in the eastern Musgraves Province to the northwest of the field site (Smits et al., 2014; Wade et 
al., 2006). Mesoproterozoic zircon dated between ca. 1.2 Ga and 1.1 Ga are probably related to magmatism within the Musgrave Province (Smithies et al., 2011) and ca. 1.1-1.0 Ga zircon is coeval with the extensive Warakurna Large Igneous Province that forms part of the Musgraves region (Wingate et al., 2004). Early Neoproterozoic (ca. $0.85 \mathrm{Ga}$ ) zircons conceivably come from magmatism associated with the Wooltana Volcanics that are found near the base of the Adelaidean System (Preiss, 1993). More problematic are Cryogenian zircons as magmatism is absent in the region, making the ca. 650 to 690 Ma zircons exotic to eastern Australia, however, these young ages provide a maximum depositional age of $654 \pm 11$ $\mathrm{Ma}(2 \sigma)$ for the top of the Bolla Bollana. Interestingly, the youngest zircon from the basal Bolla Bollana gives a maximum depositional age of $673 \pm 14 \mathrm{Ma}(2 \sigma)$. This age implies that much of the stratigraphic history of the early Cryogenian is missing (i.e. ca. $40 \mathrm{Myr}$ ) in the northern extent of the Adelaidean succession.

\section{Is deglaciation globally synchronous?}

Our new $\mathrm{U}-\mathrm{Pb}$ age of $663.03 \pm 0.11 \mathrm{Ma}(2 \sigma)$ for the Sturtian tuff that is interbedded with diamictite of the Bolla Bollana Formation, is consistent with the previously published ReOs ages of $645.1 \pm 4.8 \mathrm{Ma}(2 \sigma)$ and $647 \pm 10 \mathrm{Ma}(2 \sigma)$ on the disconformably overlying Tapley Hill Formation, as well as the $657 \pm 5.4 \mathrm{Ma}(2 \sigma)$ age from the Aralka Formation, a correlative unit to the Tapley Hill Formation in the Amadeus Basin of the Northern Territory of Australia. Furthermore, the ca. $663 \mathrm{Ma}$ age is supported by a maximum depositional age of $654 \pm 11 \mathrm{Ma}$ $(2 \sigma)$ derived from detrital zircons from the Bolla Bollana Formation. It also confirms, with greater precision and accuracy, the SHRIMP age on the tuff previously reported in abstract (Fanning and Link, 2006, 2008). Given that this tuff horizon lies $\sim 80 \mathrm{~m}$ below the transgressive post-glacial Tapley Hill Formation, this age constrains termination of the Sturtian glaciation in Australia to be younger than $663.03 \pm 0.11 \mathrm{Ma}(2 \sigma)$. 
Within a global context, this new age constraint is entirely consistent with lowprecision U-Pb zircon ages in South China (Zhou et al., 2004) and Re-Os isochron ages from organic-rich deposits in North America, South China and Mongolia (Rooney et al., 2014; Rooney et al., 2015) (Fig. 5).

\section{Conclusion}

A $\mathrm{U} / \mathrm{Pb}$ zircon age of $663.03 \pm 0.11 \mathrm{Ma}(2 \sigma)$ provides the first high precision age constraint on the termination of the Sturtian glaciation globally, furthermore, this result robustly demonstrates the consilience between $\mathrm{U}-\mathrm{Pb}$ and Re-Os geochronology. While further high precision ages from globally correlatable sequences are required, a central prediction of the Snowball climate state is long lived glaciation and a rapid and globally synchronous termination. The combination of Re-Os and $\mathrm{U}-\mathrm{Pb}$ ages provides supporting evidence for a synchronous deglaciation of a Sturtian Snowball and its ca. 58 Myr duration.

\section{Acknowledgements}

GMC and MLB are supported by an Australian Research Council Linkage grant. This work was partly funded by an Australian Research Council Laureate Fellowship awarded to Z.X. Li.

\section{References}

Abbot, D.S., Voigt, A., Li, D., Hir, G.L., Pierrehumbert, R.T., Branson, M., Pollard, D., B. Koll, D.D., 2013. Robust elements of Snowball Earth atmospheric circulation and oases for life. Journal of Geophysical Research: Atmospheres 118, 6017-6027.

Allen, P.A., Etienne, J.L., 2008. Sedimentary challenge to Snowball Earth. Nature Geoscience 1, 817-825.

Bowring, S.A., Grotzinger, J.P., Condon, D.J., Ramezani, J., Newall, M.J., Allen, P.A., 2007. Geochronologic constraints on the chronostratigraphic framework of the Neoproterozoic Huqf Supergroup, Sultanate of Oman. American Journal of Science 307, 1097-1145.

Budyko, M.I., 1969. The effect of solar radiation variations on the climate of the Earth. Tellus 21, 611-619.

Cox, G.M., Halverson, G.P., Poirier, A., Le Heron, D., Strauss, J.V., Stevenson, R., 2016a. A model for Cryogenian iron formation. Earth and Planetary Science Letters 433, 280-292. 
Cox, G.M., Halverson, G.P., Stevenson, R.S., Vokaty, M., Poirier, A., Kunzmann, M., Li, Z.X., Dudás, F.Ö., Strauss, J.V., Macdonald, F.A., 2016b. Continental Flood Basalt Weathering as a Trigger for Neoproterozoic Snowball Earth. Earth and Planetary Science Letters 446, 8899.

Cox, G.M., Strauss, J.V., Halverson, G.P., Schmitz, M.D., McClelland, W.C., Stevenson, R.S., Macdonald, F.A., 2015. Kikiktat volcanics of Arctic Alaska - Melting of harzburgitic mantle associated with the Franklin large igneous province. Lithosphere 7, 275-295.

Evans, D.A.D., 2000. Stratigraphic, geochronological, and paleomagnetic constraints upon the Neoproterozoic climatic paradox. American Journal of Science 300, 347-433.

Eyles, N., Januszczak, N., 2004. 'Zipper-rift': a tectonic model for Neoproterozoic glaciations during the breakup of Rodinia after 750 Ma. Earth-Science Reviews 65, 1-73.

Fanning, C.M., Link, P.K., 2006. Constraints on the timing of the Sturtian glaciogene event from southern Australia; ie. For the true Sturtian. Geol. Soc. Am. Abs., 115.

Fanning, C.M., Link, P.K., 2008. Age constraints for the Sturtian glaciation; data from the Adelaide Geosyncline, South Australia and Pocatello Formation, Idaho, USA., Selwyn Symposium 2008. Geol. Soc. Aus. Abstracts, 57-62.

Gernon, T.M., Hincks, T.K., Tyrrell, T., Rohling, E.J., Palmer, M.R., 2016. Snowball Earth ocean chemistry driven by extensive ridge volcanism during Rodinia breakup. Nature Geosci $9,242-248$.

Godderis, Y., Donnadieu, Y., Nedelec, A., Dupre, B., Dessert, C., Grard, A., Ramstein, G., Franaois, L.M., 2003. The Sturtian "snowball" glaciation: fire and ice. Earth and Planetary Science Letters 211, 1-12.

Hand, M., Reid, A., Jagodzinski, L., 2007. Tectonic framework and evolution of the Gawler Craton, South Australia. Economic Geology 102, 1377-1395.

Harland, W.B., 1964. Evidence of late Precambrian glaciation and its significance, in: Nairn, A.E.M. (Ed.), Problems in Paleoclimatology. Interscience, London, 119-149.

Hoffman, P.F., Abbot, D.S., Ashkenazy, Y., Benn, D.I., Brocks, J.J., Cohen, P.A., Cox, G.M., Creveling, J.R., Donnadieu, Y., Erwin, D.H., Fairchild, I.J., Ferreira, D., Goodman, J.C., Halverson, G.P., Jansen, M.F., Le Hir, G., Love, G.D., Macdonald, F.A., Maloof, A.C., Partin, C.A., Ramstein, G., Rose, B.E.J., Rose, C.V., Sadler, P.M., Tziperman, E., Voigt, A., Warren, S.G., 2017. Snowball Earth climate dynamics and Cryogenian geology-geobiology. Science Advances 3 (11), e1600983.

Hoffman, P.F., Kaufman, A.J., Halverson, G.P., Schrag, D.P., 1998. A Neoproterozoic Snowball Earth. Science 281, 1342-1346.

Hoffman, P.F., Schrag, D.P., 2002. The snowball Earth hypothesis: testing the limits of global change. Terra Nova 14, 129-155.

Horton, F., 2015. Did phosphorus derived from the weathering of large igneous provinces fertilize the Neoproterozoic ocean? Geochem. Geophys. Geosyst. 16, 1723-1738. 
Howchin, W., 1901. Preliminary note on the existence of glacial beds of Cambrian age in South Australia. Transactions of the Royal Society of South Australia 21, 74-86.

Kendall, B., Creaser, R.A., Selby, D., 2006. Re-Os geochronology of postglacial black shales in Australia: Constraints on the timing of "Sturtian" glaciation. Geology 34, 729-732.

Kirschvink, J.L., 1992. Late Proterozoic Low-Latitude Global Glaciation: the Snowball Earth, in: Schopf, J.W., Klein, C. (Eds.), The Proterozoic Biosphere: A Multidisciplinary Study. Cambridge University Press, New York.

Lan, Z., Li, X., Zhu, M., Chen, Z.-Q., Zhang, Q., Li, Q., Lu, D., Liu, Y., Tang, G., 2014. A rapid and synchronous initiation of the wide spread Cryogenian glaciations. Precambrian Research 255, 401-411.

Le Heron, D.P., Busfield, M.E., Collins, A.S., 2014. Bolla Bollana boulder beds: A Neoproterozoic trough mouth fan in South Australia? Sedimentology 61, 978-995.

Le Heron, D.P., Cox, G., Trundley, A., Collins, A., 2011. Sea ice free conditions during the Sturtian glaciation (early Cryogenian), South Australia. Geology 39, 31-34.

Lechte, M.A., Wallace, M.W., 2015. Sedimentary and tectonic history of the Holowilena Ironstone, a Neoproterozoic iron formation in South Australia. Sedimentary Geology 329, 211-224.

Li, Z.-X., Evans, D.A.D., Halverson, G.P., 2013. Neoproterozoic glaciations in a revised global palaeogeography from the breakup of Rodinia to the assembly of Gondwanaland. Sedimentary Geology 294, 219-232.

Lottermoser, B.G., Ashley, P.M., 2000. Geochemistry, petrology and origin of Neoproterozoic ironstones in the eastern part of the Adelaide Geosyncline, South Australia. Precambrian Research 101, 49-67.

Macdonald, F.A., Schmitz, M.D., Crowley, J.L., Roots, C.F., Jones, D.S., Maloof, A.C., Strauss, J.V., Cohen, P.A., Johnston, D.T., Schrag, D.P., 2010. Calibrating the Cryogenian. Science 327, 1241-1243.

Macdonald, F.A., Schmitz, M.D., Strauss, J.V., Halverson, G.P., Gibson, T.M., Eyster, A., Cox, G., Mamrol, P., Crowley, J.L., 2017. Cryogenian of Yukon. Precambrian Research, Accepted 9/8/17.

Macdonald, F.A., Wordsworth, R., 2017. Initiation of Snowball Earth with volcanic sulfur aerosol emissions. Geophysical Research Letters 44, 1938-1946.

Mawson, D., Sprigg, R.C., 1950. Subdivision of the Adelaide system. Australian Journal of Science 13, 69-72.

McAvaney, S., 2012. The Cooyerdoo Granite: Paleo- and Mesoarchean basement of the Gawler Craton. MESA Journal 65, 31-40.

McKenzie, N.R., Horton, B.K., Loomis, S.E., Stockli, D.F., Planavsky, N.J., Lee, C.-T.A., 2016. Continental arc volcanism as the principal driver of icehouse-greenhouse variability. Science 352, 444-447. 
Merdith, A.S., Collins, A.S., Williams, S.E., Pisarevsky, S., Foden, J.F., Archibald, D., Blades, M.L., Alessio, B.L., Armistead, S., Plavsa, D., Clark, C., Müller, R.D., 2017. A fullplate global reconstruction of the Neoproterozoic. Gondwana Research 50, 84-134.

North, G.R., Cahalan, R.F., Coakley, J.A., 1981. Energy balance climate models. Reviews of Geophysics 19, 91-121.

Preiss, W.V., 1993. Neoproterozoic, in: Drexel, J.F., Preiss, W.V., Parker, A.J. (Eds.), The Geology of South Australia. Geological Survey of South Australia, Adelaide, 171-224.

Preiss, W.V., 2000. The Adelaide Geosyncline of South Australia and its significance in Neoproterozoic continental reconstruction. Precambrian Research 100, 21-63.

Preiss, W.V., Drexel, J.F., Reid, A.J., 2009. Definition and age of the Kooringa Member of the Skillogalee Dolomite: host for Neoproterozoic (c.790 Ma) porphyry related copper mineralisation at Burra. MESA, 19-33.

Preiss, W.V., Gostin, V.A., McKirdy, D.M., Ashley, P.M., Williams, G.E., Schmidt, P.W., 2011. Chapter 69 The glacial succession of Sturtian age in South Australia: the Yudnamutana Subgroup. Geological Society, London, Memoirs 36, 701-712.

Rooney, A.D., Macdonald, F.A., Strauss, J.V., Dudás, F.Ö., Hallmann, C., Selby, D., 2014. Re-Os geochronology and coupled Os-Sr isotope constraints on the Sturtian snowball Earth. Proceedings of the National Academy of Sciences 111 (1), 51-56;.

Rooney, A.D., Strauss, J.V., Brandon, A.D., Macdonald, F.A., 2015. A Cryogenian chronology: Two long-lasting synchronous Neoproterozoic glaciations. Geology 43, 459-462.

Sellers, W.D., 1969. A Global Climatic Model Based on the Energy Balance of the EarthAtmosphere System. Journal of Applied Meteorology 8, 392-400.

Smithies, R.H., Howard, H.M., Evins, P.M., Kirkland, C.L., Kelsey, D.E., Hand, M., Wingate, M.T.D., Collins, A.S., Belousova, E., 2011. High-Temperature Granite Magmatism, Crust-Mantle Interaction and the Mesoproterozoic Intracontinental Evolution of the Musgrave Province, Central Australia. Journal of Petrology 52, 931-958.

Smits, R.G., Collins, W.J., Hand, M., Dutch, R., Payne, J., 2014. A Proterozoic Wilson cycle identified by Hf isotopes in central Australia: Implications for the assembly of Proterozoic Australia and Rodinia. Geology 42, 231-234.

Song, G., Wang, X., Shi, X., Jiang, G., 2017. New U-Pb age constraints on the upper Banxi Group and synchrony of the Sturtian glaciation in South China. Geoscience Frontiers 8, 1161-1173.

Thompson, B.P., Coats, R.C., Mirams, R.P., Forbes, B.G., Dalgarno, C.R., Johnson, J.E., 1964. Precambrian rock groups in the Adelaide Geosyncline: a new subdivision. Geological Survey of South Australia Quarterly Geological Notes 9, 1-19.

Vermeesch, P., 2012. On the visualisation of detrital age distributions. Chemical Geology 312-313, 190-194. 
Wade, B.P., Barovich, K.M., Hand, M., Scrimgeour, I.R., Close, D.F., 2006. Evidence for Early Mesoproterozoic Arc Magmatism in the Musgrave Block, Central Australia:

Implications for Proterozoic Crustal Growth and Tectonic Reconstructions of Australia. The Journal of Geology 114, 43-63.

Williams, G.E., Schmidt, P.W., Young, G.M., 2016. Strongly seasonal Proterozoic glacial climate in low palaeolatitudes: Radically different climate system on the pre-Ediacaran Earth. Geoscience Frontiers 7, 555-571.

Wingate, M.T.D., Pirajno, F., Morris, P.A., 2004. Warakurna large igneous province: A new Mesoproterozoic large igneous province in west-central Australia. Geology 32, 105-108.

Yu, W., Algeo, T.J., Du, Y., Zhou, Q., Wang, P., Xu, Y., Yuan, L., Pan, W., 2017. Newly discovered Sturtian cap carbonate in the Nanhua Basin, South China. Precambrian Research 293, 112-130.

Zhou, C., Tucker, R., Xiao, S., Peng, Z., Yuan, X., Chen, Z., 2004. New constraints on the ages of Neoproterozoic glaciations in south China. Geology 32, 437-440. 


\section{Figure Captions}

Figure 1. (a) Aerial view of the Gammon and Willouran Ranges. (b) Geology of the Sturtian succession exposed west of Copley township. (c) Geology of the Sturtian succession exposed along the western flanks of Termination Hill on Witchelina Station. Samples locations: P1634:

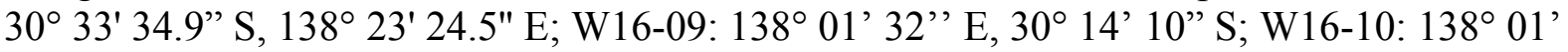
14 ” E, $30^{\circ} 13$ ' $56^{\prime \prime} \mathrm{S}$.

Figure 2. Stratigraphic log of the upper portion of the Yudnamutana Subgroup and basal Tapley Hill Formation west of Copley.

Figure 3. $\mathrm{U} / \mathrm{Pb}$ Concordia (a) and individual zircon ages (b) along with their respective $2 \sigma$ errors for tuff horizon within the Bolla Bollana Formation. Sample P1634: 30 $33^{\prime} 34.9^{\prime \prime} \mathrm{S}$, $138^{\circ} 23^{\prime} 24.5^{\prime \prime}$ E (Figure 1b).

Figure 4. (a-b) Detrital zircon spectrum for samples from the Bolla Bollana Formation. W1609: $138^{\circ} 01$ ' 32' E, 30 14' 10" S; W16-10: $138^{\circ} 01$ ' 14” E, 30 13' 56" S (Figure 1c). (c-d) Kernel density estimate of the same samples as (a) and (b). Plots constructed using DensityPlotter (Vermeesch, 2012). Grey curve is all zircons while black curve are zircons with concordancy between $>95 \%$ and $<105 \%$. Concordancy is defined as the ratio of the ${ }^{207} \mathrm{~Pb} /{ }^{206} \mathrm{~Pb}$ age to ${ }^{206} \mathrm{~Pb} /{ }^{238} \mathrm{U}$ age.

Figure 5. Compilation of U-Pb (Bowring et al., 2007; Cox et al., 2015; Fanning and Link, 2008; Lan et al., 2014; Macdonald et al., 2010; Macdonald et al., 2017; Song et al., 2017; Yu et al., 2017; Zhou et al., 2004) and Re-Os ages (Kendall et al., 2006; Rooney et al., 2014; Rooney et al., 2015) for the onset and termination of the Sturtian glaciation. For our new CA-ID-TIMS age, when tracer calibration and ${ }^{238} \mathrm{U}$ decay constant uncertainties are propagated in quadrature, the total error is $663.03 \pm 0.76 \mathrm{Ma}(2 \sigma)$, which should be considered when comparing our dates with those derived from the ${ }^{187} \mathrm{Re}^{187} \mathrm{Os}$ decay scheme. All errors are $2 \sigma$. For clarity some Laurentian ages listed in Table 1 are not reproduced here. Arrows indicate maximum and minimum age constraints.

\section{Table Captions}

Table 1. Compilation of U-Pb (Bowring et al., 2007; Cox et al., 2015; Fanning and Link, 2008; Lan et al., 2014; Macdonald et al., 2010; Macdonald et al., 2017; Song et al., 2017; Yu et al., 2017; Zhou et al., 2004) and Re-Os ages (Kendall et al., 2006; Rooney et al., 2014; Rooney et al., 2015) for the onset and termination of the Sturtian glaciation. All U/Pb ages are ${ }^{206} \mathrm{~Pb} /{ }^{238} \mathrm{U}$ ages except Zhou et al., 2004 which is a ${ }^{207} \mathrm{~Pb} /{ }^{206} \mathrm{~Pb}$ age. All errors are $2 \sigma$. 


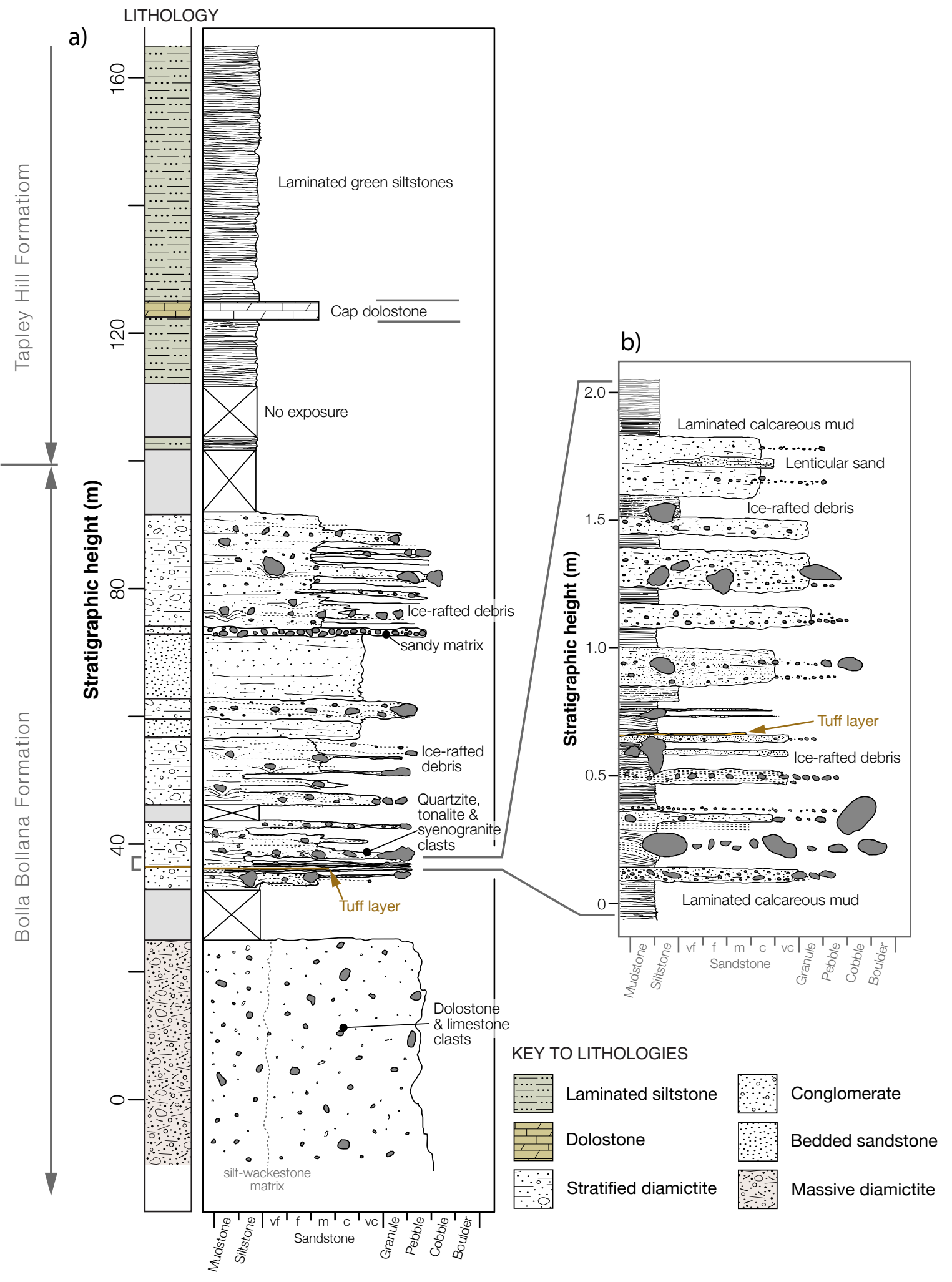




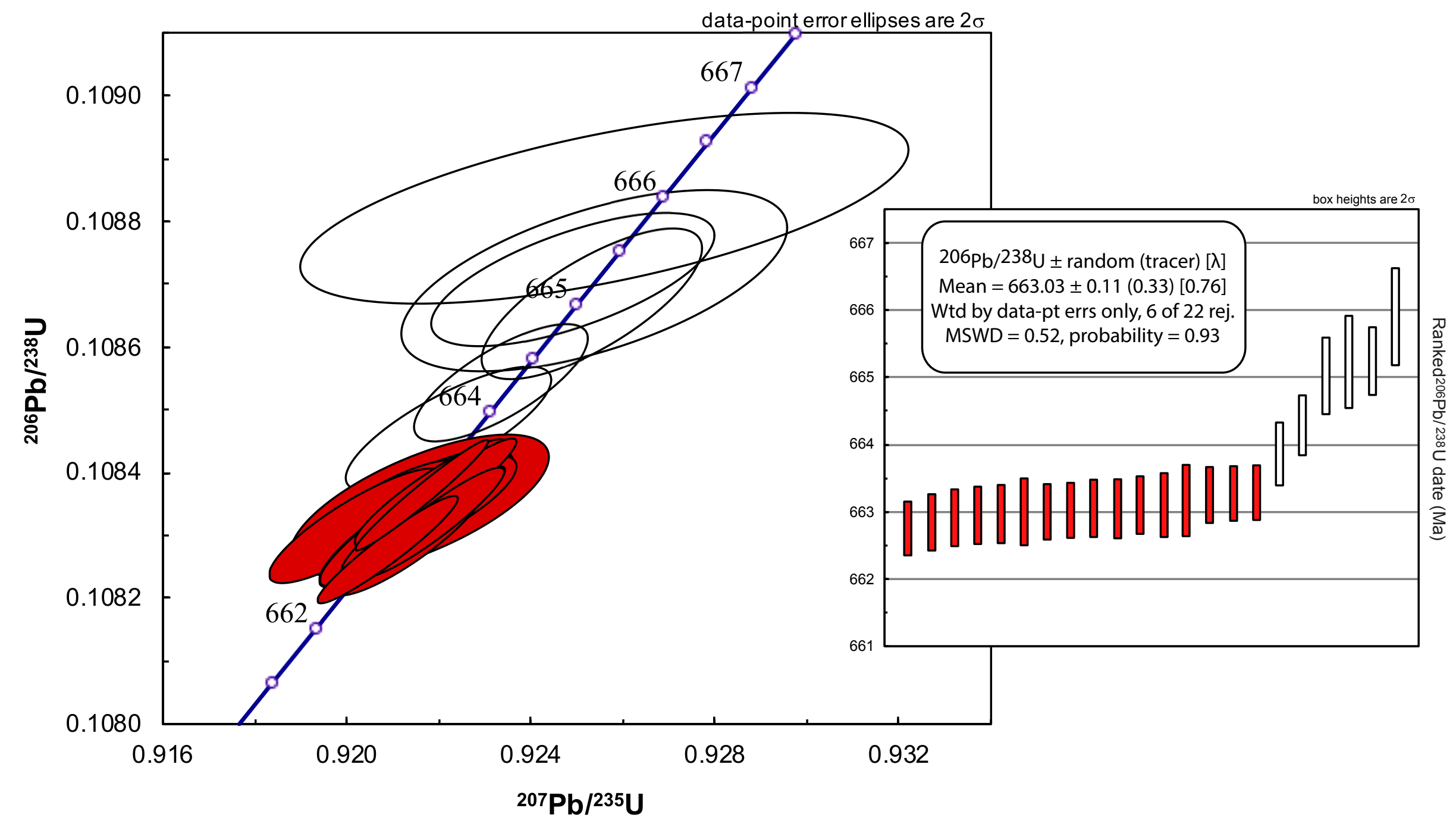




\section{STURTIAN GLACIATION}

(58 Myr)

\section{ONSET}

\section{$720715 \quad 710$}

पागामापा

Oman

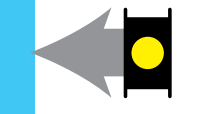

South China

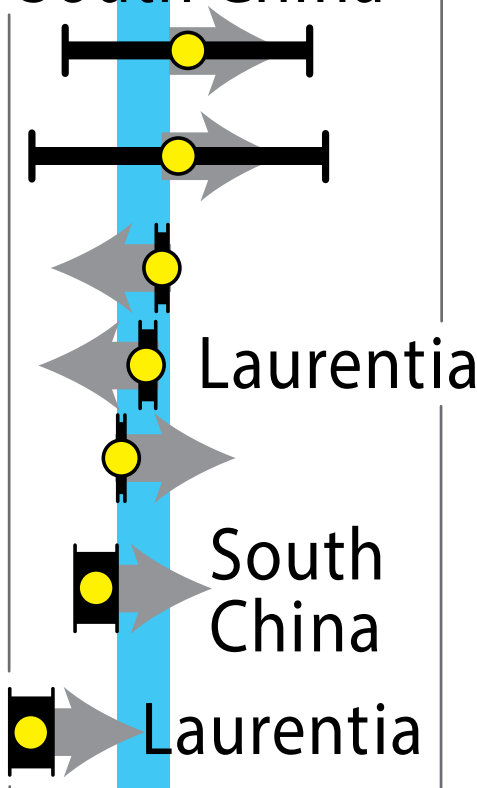

TERMINATION $665 \quad 660 \quad 655$

חיד Australia

South China Mongolia

South China

\section{Laurentia}

Australia

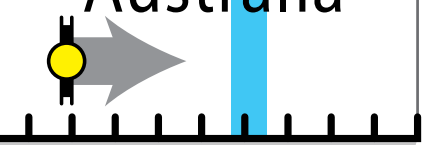

Sturtian epoch

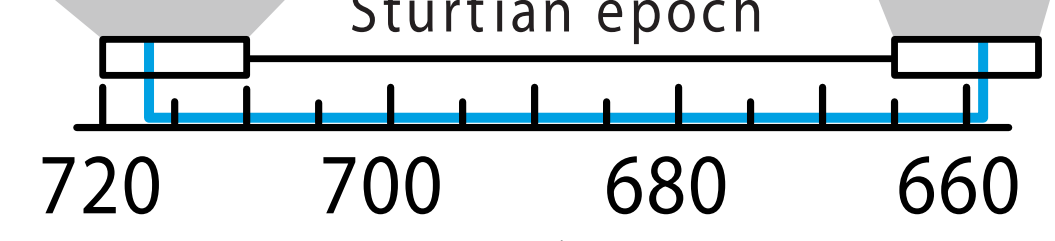

$\mathrm{FOA}$ U-Pb SIMS

a U-Pb CA-ID-TIMS

$=\mathrm{O}$ Re-Os

$\max$.

$\min$. 


\begin{tabular}{|l|c|l|l|}
\hline \multicolumn{5}{|l|}{ a) Age constraints for the onset of Sturtian glaciation } \\
\hline Oman & $713.7 \pm 0.5$ & U-Pb CA-ID-TIMS & Bowring et. al., 2007 \\
\hline South China & $714.6 \pm 5.2$ & U-Pb LA-ICP-MS & Song et. al., 2017 \\
\hline South China & $715.9 \pm 2.8$ & U-Pb SIMS & Lan et. al., 2014 \\
\hline Laurentia & $716.5 \pm 0.2$ & U-Pb CA-ID-TIMS & Macdonald et. al., 2010 \\
\hline Laurentia & $717.4 \pm 0.1$ & U-Pb CA-ID-TIMS & Macdonald et. al., 2010 \\
\hline Laurentia & $719.47 \pm 0.29$ & U-Pb CA-ID-TIMS & Cox et. al. 2015 \\
\hline Laurentia & $716.5 \pm 0.2$ & U-Pb CA-ID-TIMS & Macdonald et. al., 2017 \\
\hline Laurentia & $716.9 \pm 0.4$ & U-Pb CA-ID-TIMS & Macdonald et. al., 2017 \\
\hline Laurentia & $717.4 \pm 0.2$ & U-Pb CA-ID-TIMS & Macdonald et. al., 2017 \\
\hline Laurentia & $717.7 \pm 0.3$ & U-Pb CA-ID-TIMS & Macdonald et. al., 2017 \\
\hline Laurentia & $717.8 \pm 0.2$ & U-Pb CA-ID-TIMS & Macdonald et. al., 2017 \\
\hline b) Age constraints for the termination of Sturtian glaciation & \\
\hline Australia & $645.1 \pm 4.8$ & Re-Os & Kendall et. al., 2006 \\
\hline Australia & $647 \pm 10$ & Re-Os & Kendall et. al., 2006 \\
\hline Australia & $657.2 \pm 5.4$ & Re-Os & Kendall et. al., 2006 \\
\hline Tuva-Mongolia & $659.0 \pm 4.5$ & Re-Os & Rooney et. al., 2015 \\
\hline Australia & $659.7 \pm 5.3$ & U-Pb SIMS & Fanning et. al., 2008 \\
\hline Laurentia & $662.4 \pm 3.9$ & Re-Os & Rooney et. al. 2014 \\
\hline South China & $662.7 \pm 6.2$ & U-Pb LA-ICP-MS & Yu et. al., 2017 \\
\hline South China & $662.9 \pm 4.3$ & U-Pb ID-TIMS & Zhou et. al., 2004 \\
\hline
\end{tabular}

